\title{
Novel small molecule protein arginine deiminase 4 (PAD4) inhibitors
}

\author{
Murat Bozdag ${ }^{\mathrm{a}}$, Tobias Dreker ${ }^{\mathrm{c}}$, Christophe Henry ${ }^{\mathrm{d}}$, Paolo Tosco ${ }^{\mathrm{e}}$, Maura Vallaro ${ }^{\mathrm{e}}$, Roberta Fruttero ${ }^{\mathrm{e}}$, \\ Andrea Scozzafava ${ }^{a}$, Fabrizio Carta ${ }^{\mathrm{a}, *}$, Claudiu T. Supuran ${ }^{\mathrm{a}, \mathrm{b}, *}$ \\ a Università degli Studi di Firenze, Polo Scientifico, Laboratorio di Chimica Bioinorganica, Rm. 188, Via della Lastruccia 3, 50019 Sesto Fiorentino, Florence, Italy \\ ${ }^{\mathrm{b}}$ Università degli Studi di Firenze, Dipartimento di Scienze Farmaceutiche, Via Ugo Schiff 6, 50019 Sesto Fiorentino, Florence, Italy \\ ' 4SC AG, Am Klopferspitz 19a, 82152 Planegg-Martinsried, Germany \\ d 4 SC Discovery GmbH, Am Klopferspitz 19a, 82152 Planegg-Martinsried, Germany \\ e Università degli Studi di Torino, Dipartimento di Scienza e Tecnologia del Farmaco, Via Pietro Giuria 9, 10125 Torino, Italy
}

\section{A R T I C L E I N F O}

\section{Article history:}

Received 25 October 2012

Revised 21 November 2012

Accepted 22 November 2012

Available online 2 December 2012

\section{Keywords:}

PAD inhibitors

CA inhibitors

Rheumatoid arthritis

Cancer

\begin{abstract}
A B S T R A C T
Protein arginin deaminase 4 (PAD4) is a calcium dependent enzyme which catalyses the conversion of peptidyl-arginine into peptidyl-citrulline and is implicated in several diseases such as rheumatoid arthritis (RA) and cancer. Herein we report the discovery of novel small-molecule, non peptidic PAD4 inhibitors incorporating primary/secondary guanidine moieties.
\end{abstract}

() 2012 Elsevier Ltd. All rights reserved.
We recently reported that phenols and aryl/alkyl carboxylic acids act as carbonic anhydrase (CA, EC 4.2.1.1) inhibitors (CAI), characterized by a different mechanism of action compared to the classical inhibitors of these enzymes, that is, the sulfonamides/sulfamates/sulfamides. ${ }^{1}$ During our investigations in the field of CAIs, we started to explore the introduction of the guanidine moiety on phenyl rings bearing simple functionalities (such as phenol, carboxylate and/or sulfonamide), with the intent to introduce a polar group able to interact with the enzyme active site through hydrophilic interactions. Our investigation on compounds bearing the guanidine functionality brought our attention to another class of enzyme where the guanidine group acts as a substrate, namely the protein arginine deiminases (PADs). PADs are $\mathrm{Ca}^{2+}$-dependent enzymes which catalyse the conversion of arginine residues to citrulline ones through a hydrolytic process generally referred to as citrullination. They belong to the superfamily of amidinotransferases, which arewidely present in both eukaryotic and prokaryotic organisms. ${ }^{2}$ To date, five PAD isozymes are known in humans, distributed across different tissues and cell compartments. ${ }^{3-5}$ For example, the PAD1 isoform is expressed in epidermis and it was proven to be involved in keratinisation processes, ${ }^{3,4}$ whereas PAD2 is mainly present in muscle and brain tissues. ${ }^{5}$ Experiments in mice are strongly indicative of the role played by

\footnotetext{
* Corresponding authors. Tel.: +39055 457 3005; fax: +39 0554573385 .

E-mail addresses: fabrizio.carta@unifi.it (F. Carta), claudiu.supuran@unifi.it (C.T. Supuran).
}

PAD2 in the formation of the myelin basic protein (MBP), which in turn is involved in the myelin maturation process within the central nervous system. ${ }^{6}$ Moreover, Wood et al. found evidence that multiple sclerosis is associated to heavy citrullination of MBPs and neuron demyelination. ${ }^{7}$ PAD3 is expressed in hair follicles, ${ }^{8,9}$ whereas PAD4 (previously referred to as PAD V) is mainly expressed in granulocytes and is the only isoform localized in the cell nucleus. ${ }^{10-12}$ Finally, PAD6 is present in egg cells and embryos. ${ }^{13,14}$

Among these isoforms, PAD4 is the most investigated one, its mode of action as well as its structure being assumed as model for the other ones, since there is a strict homology sequence within the human PAD series. $8,10,13,15,16$ PAD4 is a $74 \mathrm{kDa}$ protein of 663 aminoacids. Structural investigations reported the apoprotein PAD4 having 5 sites highly specific for binding $\mathrm{Ca}^{2+}$ ions. Once it is in loco, the protein undergoes a conformational change, which generates the catalytic site located at the C-terminal domain, and promotes a rearrangement and stabilization of the $\mathrm{N}$-terminal domain. ${ }^{17}$ The functional implications for the immunoglobulin-like folding of the $\mathrm{N}$-terminal domain are somewhat related to signal transduction and/or regulatory mechanisms of this protein and are not yet fully understood. Apart from the intracellular $\mathrm{Ca}^{2+}$ concentration regulation, there may be other mechanisms involved in the fine tuning of PAD activity. In fact, the physiological intracellular concentrations of $\mathrm{Ca}^{2+}$ do not exceed the low micromolar values ( $\sim 1 \mu \mathrm{M}$ maximum in activated cells), which is quite far from the calcium $\mathrm{K}_{0.5}{ }^{18}$ registered until now for PAD4, using benzoylated arginine derivatives as substrates. ${ }^{19,20}$ The dependence on calcium, 
which in turn is also substrate-dependent, is indeed the major intrinsic regulatory mechanism for PAD4, even if no compound has been reported to date with the ability to bind PAD4 and restore physiological $K_{0.5}$ calcium values. Furthermore, alternative modulatory mechanisms such as proteolytic splicing and proteinprotein interactions may be involved in PAD regulation. ${ }^{21}$

Many aspects of PAD4 biochemistry and physiology still need to be addressed and investigated. For example, PAD4 has a well-defined role in the pathophysiology of some diseases. It is accepted that PAD4 dysregulation has a causative effect in rheumatoid arthritis, since massive citrullination of peptidyl-arginine residues triggers an autoimmune response in genetically disposed individuals. $^{22,23}$ Furthermore, bacteria infecting the host organism may contribute to the amount of citrullinated residues. ${ }^{24}$ PAD4 acts as a transcriptional regulator by deiminating $\mathrm{H} 2 \mathrm{~A}, \mathrm{H} 3$ and $\mathrm{H} 4$ histones, thus making this enzyme a validated and attractive target for the treatment of cancer. ${ }^{25,26}$

In this work, we investigated a series of compounds bearing the primary/secondary guanidine group as in structures 1-11, except for 12 (Scheme 1), and we assessed their PAD4 inhibitory activity (see Table 2). Benzoyl-L-arginine derivatives such as BAEE and BAME are well-known PAD4 substrates. Their structures as well as their kinetic parameters are reported in Table $1 .^{27}$

$\mathrm{IC}_{50}$ values or percentage of inhibition data are generated by two classical methods, which involve chemical reactions with either the citrullinated amino acid or the ammonia side product. The first one is based on the quantification of the citrullinated BAEE formed in the presence of the inhibitor molecule, which is titrated with a diacetylmonoximethiosemicarbazone (DTZ) to form a red-colored absorbing species after subsequent oxidative aromatization. ${ }^{28}$ The second method consists in measuring the amount of released molecular ammonia as consequence of BAEE citrullination. The imine intermediate, formed in a first step by reaction of the ammonia with ortho-phtalaldehyde (OPT) is then cyclized with dithiothreitol (DDT) to produce a fluorescent isoindole. ${ }^{29}$ In our hands, these two assays proved to be enough sensitive and reproducible on different sets of chemotypes. Nevertheless, they both require quite a large amount of PAD4 protein and this prompted us to consider an alternative protocol. To identify PAD inhibitors a commercially available antibody based assay was obtained from Modiquest Research, AJ Nijmegen, The Netherlands. The assay determines the amount of citrulline generated by PAD4 through conversion of arginines contained in peptides coated to the bottom of the reaction wells. To perform a fast screening approach test compounds were added to each reaction in concentrations of 1 and $10 \mu \mathrm{M}$, respectively. Inhibitory activity is represented as the difference in percent between the normalized signals of the control reaction containing DMSO and the reaction in presence of compound. Since variations in absolute inhibition values in different assay systems and with different substrates are not uncommon, $\mathrm{Cl}$-amidine, an electrophilic molecule which is reported to inhibit PAD4 by covalent modification with an $\mathrm{IC}_{50}$ value of $5.9 \mu \mathrm{M},{ }^{30}$ was tested in parallel in the experiment to evaluate inhibition potency. ${ }^{31}$

First we explored the inhibitory effect on PAD4 of the simple guanidines 1-3, which were prepared by reaction of cyanamide with the corresponding anilines or amine. ${ }^{32}$ Compounds $\mathbf{1}$ and $\mathbf{2}$, which bear the aryl guanidine moiety, showed modest inhibitory activities ( $4 \%$ at $1 \mu \mathrm{M}$ and $6 \%$ at $10 \mu \mathrm{M}$ for $1,3 \%$ for both concentrations for 2). The introduction of an ethyl spacer between the phenyl ring and the guanidine group, as in $\mathbf{3}$, resulted in a drop of the activity to $1 \%$ at $1 \mu \mathrm{M}$. Subsequently, cimetidine (4), a well-known $\mathrm{H}_{2}$-antagonist, was also considered as a potential PAD inhibitor, but it turned out to be ineffective ( $1 \%$ at $1 \mu \mathrm{M}$ and $0 \%$ at $10 \mu \mathrm{M})$. Such result was not surprising, since the PAD4 enzymatic cleft is narrow and cannot accommodate the bulky cyano-guanidine
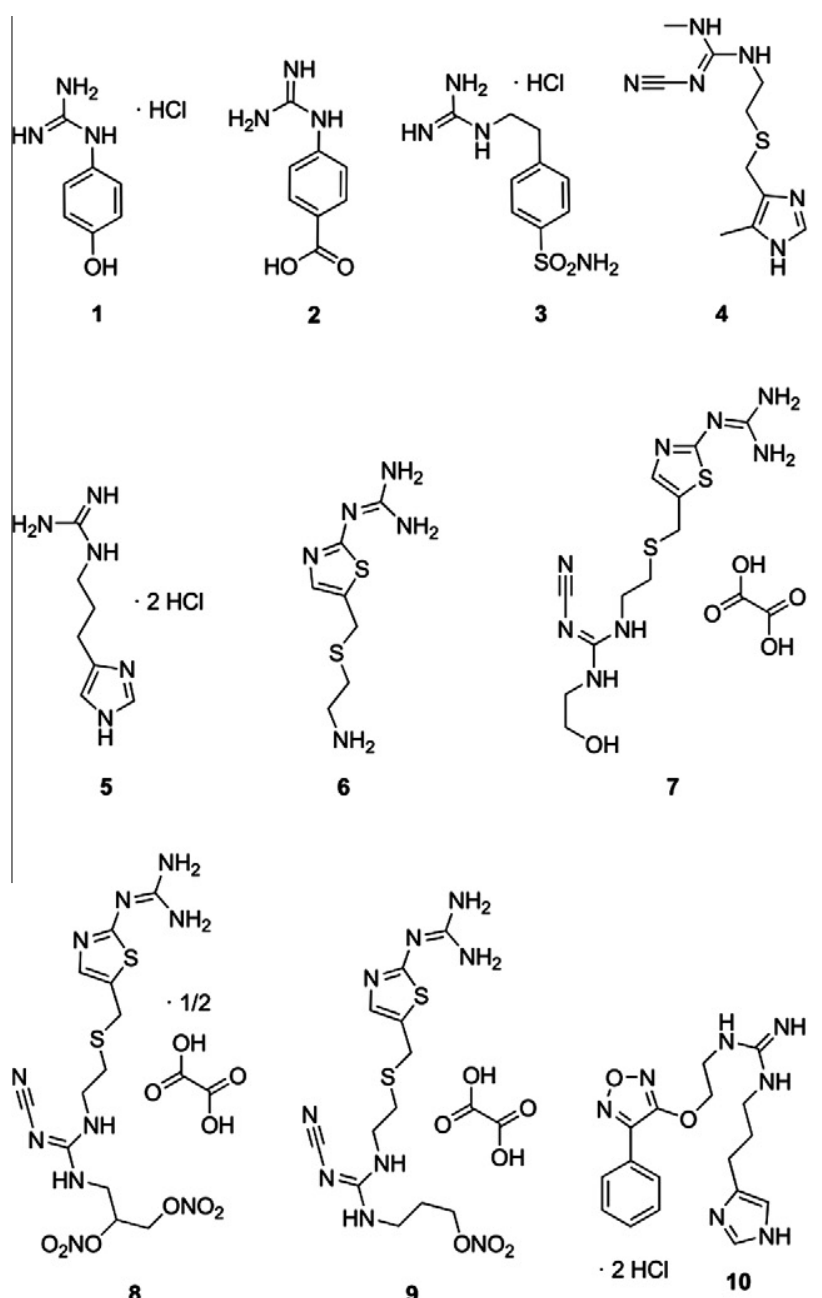<smiles>N#C/N=C(/NCCCO[N+](=O)[O-])NCCSCc1cnc(N=C(N)N)s1</smiles><smiles>N=C(NCCCc1c[nH]cn1)NCCOc1nonc1-c1ccccc1</smiles>

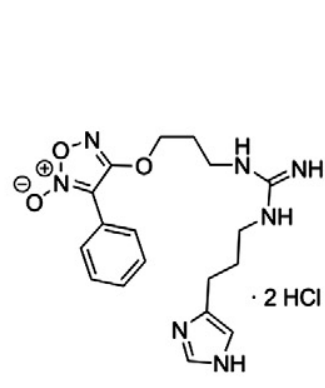

11

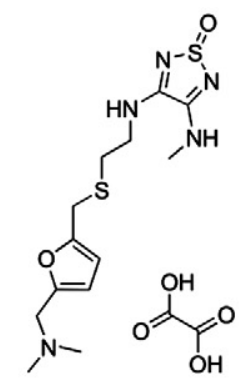

12
Scheme 1. Structures of compounds 1-12.

group, which according to docking simulations ${ }^{33}$ is forced to lie at the mouth of the enzyme cavity (Fig. 1A). A better inhibitory potency ( $6 \%$ at $1 \mu \mathrm{M}$ and $7 \%$ at $10 \mu \mathrm{M}$ ) was observed for (5), a selective $\mathrm{H}_{3}$-antagonist. This compound is structurally related to cimetidine, except for the shorter alkyl chain connecting the heteroring with the unsubstituted guanidine group.

Finally, we moved to the guanidine derivatives 6-11 and compound 12, which are part of a wide library of imidazole derivatives originally designed as $\mathrm{H}_{2} / \mathrm{H}_{3}$-antagonists $\left(\mathbf{6 - 9} ;^{34} \mathbf{1 0 , 1 1} ; ;^{35} \mathbf{1 2}^{36}\right)$. The purity of the tested compounds was $>95 \%$ (HPLC detection), with the sole exception of $\mathbf{9}(92 \%)$. The simple terminal heteroaryl guanidine derivative $\mathbf{6}$ was a rather weak inhibitor ( $1 \%$ at $1 \mu \mathrm{M}$ and $5 \%$ at $10 \mu \mathrm{M}$ ). However, the introduction of nitrooxy esters, potentially able to anchor to the top entrance of the enzyme cavity via 
Table 1

Kinetic parameters for arginine containing PAD4 substrates. ${ }^{27}$<smiles>[R]C(=O)[C@H](CCCNC(N)=[NH2+])NC(=O)c1ccccc1</smiles>

\begin{tabular}{llll}
\hline Compound & $\mathrm{R}$ & $K_{\mathrm{m}}(\mathrm{mM})$ & $K_{\text {cat }}\left(\mathrm{s}^{-1}\right)$ \\
\hline BAEE & OEt & $1.36 \pm 0.19$ & $5.94 \pm 0.26$ \\
BAME & OEt & $1.66 \pm 0.26$ & $5.57 \pm 0.28$ \\
BA & OH & $0.41 \pm 0.04$ & $3.35 \pm 0.12$ \\
BAA & $\mathrm{NH}_{2}$ & $0.25 \pm 0.06$ & $2.76 \pm 0.16$ \\
\hline
\end{tabular}

Table 2

ABAP assay results at 1 and $10 \mu \mathrm{M}$ concentration of inhibitor

\begin{tabular}{lcc}
\hline Compound $^{\mathrm{a}}$ & \multicolumn{2}{c}{$(\%)$ Inhibition $^{\mathrm{b}}$} \\
\cline { 2 - 3 } & ABAP at $1 \mu \mathrm{M}$ & ABAP at $10 \mu \mathrm{M}$ \\
\hline $\mathbf{1}$ & 4 & 6 \\
$\mathbf{2}$ & 3 & 3 \\
$\mathbf{3}$ & 1 & 5 \\
$\mathbf{4}$ & 0 & 1 \\
$\mathbf{5}$ & 6 & 7 \\
$\mathbf{6}$ & 1 & 5 \\
$\mathbf{7}$ & 2 & 3 \\
$\mathbf{8}$ & 3 & 8 \\
$\mathbf{9}$ & 1 & 10 \\
$\mathbf{1 0}$ & 2 & 34 \\
$\mathbf{1 1}$ & 8 & 36 \\
$\mathbf{1 2}$ & 0 & 9 \\
Cl-amidine $^{\mathrm{c}}$ & 18 & 35 \\
\hline
\end{tabular}

a All compounds were assayed in duplicate.

bata are expressed as percentage of inhibition.

c $\mathrm{Cl}$-amidine from Calbiochem was tested in the same experiment.

hydrogen bonding interactions, resulted in a sensible increase of the PAD4 inhibitory activity (3\% at $1 \mu \mathrm{M}, 8 \%$ at $10 \mu \mathrm{M}$ for 8 and $1 \%$ at $1 \mu \mathrm{M}, 10 \%$ at $10 \mu \mathrm{M}$ for 9). Another interesting compound in the series was 12, which has no guanidine group while it bears a methylamino-substituted sulfothiadiazole terminal moiety. Even though 12 showed a weak inhibitory activity $(0 \%$ at $1 \mu \mathrm{M}, 9 \%$ at $10 \mu \mathrm{M}$ ), its scaffold lacks the classical structural features required for PAD inhibition. All structures discussed until now show inhibitory potencies ranging from 0 to $10 \%$ at 1 and $10 \mu \mathrm{M}$. Furthermore the differences in inhibition percentages for each compound, at both concentrations, are very narrow, thus not allowing to assess a proper discrimination in terms of activity. Therefore we can simply summarize them as very weak or not inhibitors at all for PAD4.Quite unexpected was the inhibitory activity for $\mathbf{1 0}$ and $\mathbf{1 1}$ (2\% at $1 \mu \mathrm{M}, 34 \%$ at $10 \mu \mathrm{M}$ for $10 ; 8 \%$ at $1 \mu \mathrm{M}, 36 \%$ at $10 \mu \mathrm{M}$ for 11 ). Both structures have the guanidine group placed in the central region of the molecule and they were not expected to have good interactions with the enzymatic cavity, that is, to act as PAD inhibitors. Docking simulations suggest that the guanidine moiety in $\mathbf{1 0}$ and $\mathbf{1 1}$ interacts with Asp323 and His613, while the imidazole ring establishes hydrogen bonds with His610 and Glu615, and the 1,2,5-oxadiazole system interacts with Arg347 at the mouth of the binding site (Fig. 1B).

Compounds 1-3 were also tested as CA inhibitors ${ }^{37}$ (see Table 3 ). They all showed inhibitory activities in line with the
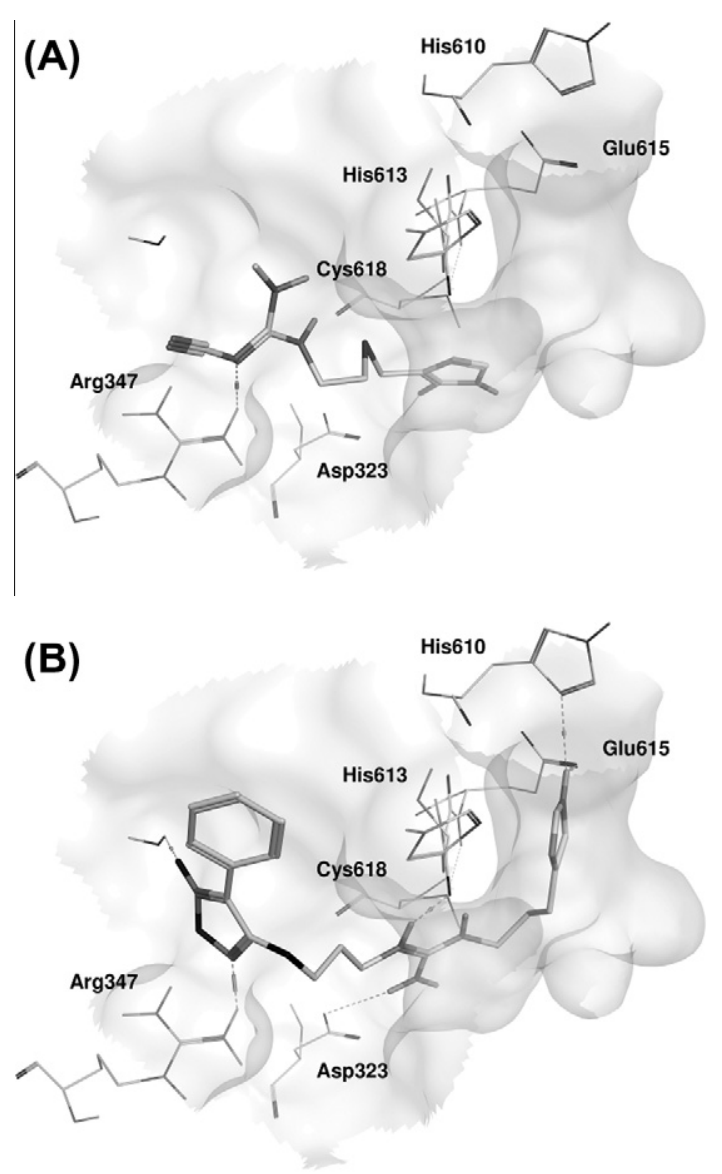

Figure 1. Docking poses of compounds 4 (A) and 11, (B) in the human PAD4 binding site (PDB ID 3B1U).

Table 3

CA I, II, IX, XII inhibition data of compounds 1-3 for the $\mathrm{CO}_{2}$ hydration reaction (stopped-flow assay) at $20^{\circ} \mathrm{C}$

\begin{tabular}{lclll}
\hline \multirow{2}{*}{ Compound } & \multicolumn{4}{c}{$K_{\mathrm{i}}(\mu \mathrm{M})$} \\
\cline { 2 - 5 } & hCA I & hCA II & hCA IX & hCA XII \\
\hline $\mathbf{1}$ & 8.34 & 7.51 & 4.13 & 14.6 \\
$\mathbf{2}$ & 0.63 & 1.15 & 2.56 & 0.48 \\
$\mathbf{3}$ & 0.24 & 0.089 & 0.034 & 0.014 \\
Phenol $^{\mathrm{a}}$ & 10.2 & 5.5 & 8.8 & 9.2 \\
Acetazolamide $^{\mathrm{a}}$ & 0.250 & 0.012 & 0.025 & 0.0057 \\
\hline
\end{tabular}

a See Ref. 1a.

parent phenolic, aryl carboxylate and benzenesulfonamide structures. The introduction of the guanidine group is not associated with appreciable selectivity for the cytosolic and the membranebound isozymes.

In conclusion, we report a series of small non peptidic compounds tested for PAD4 inhibition. Among them, structures 10 and 11 showed appreciable inhibitory activity (up to 36\% inhibition at $10 \mu \mathrm{M}$ concentration). The inhibitory potency of these compounds is therefore comparable to the electrophile $\mathrm{Cl}$-amidine, one of the most potent amidine-based small molecule PAD4 inhibitor described in the literature so far. ${ }^{44}$ In contrast to $\mathrm{Cl}$-amidine, which acts by irreversible covalent inhibition of PAD4, structures $\mathbf{1 0}$ and 11 most likely exhibit a different mechanism, which could be used to address potential specificity issues. Indeed, non-covalent inhibition with non-electrophilic molecules could present the advantage to offer more selectivity among the PAD family of enzymes (e.g., 
PAD2 vs PAD4) and versus other cysteine-containing biological nucleophiles like Cathepsin K or glutathione. Interestingly, docking simulations indicate a peculiar binding mode which exploits both the guanidine and the imidazole moiety as hydrogen bonding partners of hydrophilic residues in the enzyme cleft. Moreover, compounds 1-3 were also considered for their CA inhibitory activity as they bear phenolic, carboxylate and sulfonamide groups which are known zinc-binding groups.

\section{Acknowledgements}

M.B., T.D., C.H., A.S., F.C. and C.T.S. are grateful to Gums \& Joints for financial support (Grant agreement: HEALTH-F2-2010261460). The Chemical Computing Group is acknowledged for financial support to computational work and Professor A. Gasco for helpful discussions.

\section{References and note}

1. (a) Innocenti, A.; Vullo, D.; Scozzafava, A.; Supuran, C. T. Bioorg. Med. Chem. Lett. 2008, 18, 1583; (b) Innocenti, A.; Vullo, D.; Scozzafava, A.; Supuran, C. T. Bioorg. Med. Chem. Lett. 2008, 16, 7424; (c) Carta, F.; Vullo, D.; Maresca, A.; Scozzafava, A.; Supuran, C. T. Bioorg. Med. Chem. Lett. 2012. in press, and references therein. 2. Shirai, H.; Blundell, T. L.; Mizuguchi, K. Trends Biochem. Sci. 2001, 26, 465.

3. Senshu, T.; Aliyama, K.; Ishigami, A.; Nomura, K. J. Dermatol. Sci. 1999, 21, 113.

4. Ishida-Yamamoto, A.; Senshu, T.; Eady, R. A.; Takahashi, H.; Shimizu, H.; Akiyama, M.; Iizuka, H. J. Invest. Dermatol. 2002, 118, 282.

5. Moscarello, M. A.; Pritzker, L. B.; Mastronardi, F. G.; Wood, D. D. J. Neurochem. 2002, 81, 335.

6. Pritzker, L. B.; Nguyen, T. A.; Moscarello, M. A. Neurosci. Lett. 1999, 266, 161.

7. Wood, D. D.; Bilbao, J. M.; O’Connors, P.; Moscarello, M. A. Ann. Neurol. 1996, 40, 18.

8. Kanno, T.; Kawada, A.; Yamanouchi, J.; Yosida-Noro, C.; Yoshiki, A.; Shiraiwa, M.; Kusakabe, M.; Manabe, M.; Tezuka, T.; Takahara, H.J. Invest. Dermatol. 2000, $115,813$.

9. Rogers, G.; Winter, B.; McLaughlan, C.; Powell, B.; Nesci, T. J. Invest. Dermatol. 1997, 108, 700.

10. Nakashima, K.; Hagiwara, T.; Ishigami, A.; Nagata, S.; Asaga, H.; Kuramoto, M.; Senshu, T.; Yamada, M. J. Biol. Chem. 1999, 274, 27786.

11. Hagiwara, T.; Nakashima, K.; Hirano, H.; Senshu, T.; Yamada, M. Biochem. Biophys. Res. Commun. 2002, 290, 979.

12. Nakashima, K.; Hagiwara, T.; Yamada, M. J. Biol. Chem. 2002, 277, 49562.

13. Chavanas, S.; Méchin, M. C.; Takahara, H.; Kawada, A.; Nachat, R.; Serre, G.; Simon, M. Gene 2004, 330, 19.

14. Wright, P. W.; Bolling, L. C.; Calvert, M. E.; Sarmento, O. F.; Berkeley, E. V.; Shea, M. C.; Hao, Z.; Jayes, F. C.; Bush, L. A.; Shetty, J.; Shore, A. N.; Reddi, P. P.; Tung, K. S.; Samy, E.; Allietta, M. M.; Sherman, N. E.; Herr, J. C.; Coonrod, S. A. Dev. Biol. 2003, 256, 74 .

15. Guerrin, M.; Ishigami, A.; Méchin, M. C.; Nachat, R.; Valmary, S.; Sebbag, M.; Simon, M.; Senshu, T.; Serre, G. Biochem. J. 2003, 370, 167.

16. Ishigami, A.; Ohsawa, T.; Asaga, H.; Akiyama, K.; Kuramoto, M.; Maruyama, N. Arch. Biochem. Biophys. 2002, 407, 25.

17. Arita, K.; Hashimoto, H.; Shimizu, T.; Nakashima, K.; Yamada, M.; Sato, M. Nat. Struct. Biol. 2004, 11, 777.

18. $K_{0.5}$ is defined as the concentration of calcium corresponding to half of the maximal enzyme activity.

19. Lewis, R. S. Annu. Rev. Immunol. 2001, 19, 497.

20. Takahara, H.; Tsuchida, M.; Kusubata, M.; Akutsu, K.; Tagami, S.; Sugawara, K. J. Biol. Chem. 1989, 264, 13361.

21. Slack, J. L.; Jones, L. E., Jr.; Bhatia, M. M.; Thompson, P. R. Biochemistry 2011, 50, 3997.

22. Klareskog, L.; Rönnelid, J.; Lundberg, K.; Padyukov, L.; Alfredsson, L. Annu. Rev. Immunol. 2008, 26, 651 .

23. Wegner, N.; Lundberg, K.; Kinloch, A.; Fisher, B.; Malmström, V.; Feldmann, M.; Venables, P. J. Immunol. Rev. 2010, 233, 34.

24. Lundberg, K.; Wegner, N.; Yucel-Lindberg, T.; Venables, P. J. Nat. Rev. Rheumatol. 2010, 12, 727.

25. Thompson, P. R.; Fast, W. ACS Chem. Biol. 2006, 7, 433.

26. Slack, J. L.; Causey, C. P.; Thompson, P. R. Cell Mol. 2011, 68, 709.

27. Kearney, P. L.; Bhatia, M.; Jones, N. G.; Yuan, L.; Glascock, M. C.; Catchings, K. L.; Yamada, M.; Thompson, P. R. Biochemistry 2005, 44, 10570.

28. Yuki, H.; Ohmura, T.; Kawasaki, H.; Yajima, T.; Saito, K. Chem. Pharm. Bull. 1981, 29, 1096.

29. (a) Sugawara, K.; Oyama, O. J. Biochem. 1981, 89, 771; (b) Sternson, L. A.; Stobaugh, J. F.; Repta, A. J. Anal. Biochem. 1985, 144, 233; Mana, H. Ph.D. Thesis, Martin-Luther-Universität Halle-Wittenberg, November 1998.

30. (a) Luo, Y.; Arita, K.; Bhatia, M.; Knuckley, B.; Lee, Y. H.; Stallcup, M. R.; Sato, M.; Thompson, P. R. Biochemistry 2006, 45, 11727; (b) Knuckley, B.; Causey, C. P.; Pellechia, P. J.; Cook, P. F.; Thompson, P. R. ChemBioChem 2010, 11, 161.
31. hPAD4 enzyme is from Cayman (Item No. 10500). Antibody based assay for PAD activity (ABAP) kit from Modiquest (Cat.-No. MQ-17.101). Deimination buffer: $40 \mathrm{mM}$ Tris- $\mathrm{HCl}, 5 \mathrm{mM} \mathrm{CaCl} 2,1 \mathrm{mM}$ DTT, pH 7.5 Wash buffer: PBS w. $0.05 \%$ Tween-20.

Modified protocol from Modiquest. The antibody based kit for PAD4 activity measurements (Modiquest Research, AJ Nijmegen, The Netherlands, Cat. No. MQ-17.101-96) provides a 96-well microplate in which the bottom of each reaction well is coated with arginine containing peptides as the substrate for PAD4. Each reaction was prepared in a total volume of $100 \mu$ l deimination buffer ( $40 \mathrm{mM}$ Tris- $\mathrm{HCl}, 5 \mathrm{mM} \mathrm{CaCl}, 1 \mathrm{mM}$ DTT, pH adjusted to 7.5) containing 20 pg/ $\mu$ l PAD4 (Cayman Chemical, Ann Arbor, MI, USA, Cat. No. 10500) as well as test compound and/or 0.1\% DMSO. After preincubation for $15 \mathrm{~min}$ at $37{ }^{\circ} \mathrm{C}$ reactions were initiated by transfer to the substrate coated wells in the assay plate and kept at $37^{\circ} \mathrm{C}$ for $20 \mathrm{~min}$. Subsequently all wells were washed 5 times with $100 \mu$ l wash buffer (PBS containing $0.05 \%$ Tween-20) and incubated with $100 \mu \mathrm{l}$ mouse anti-deiminated-arginine antibody (as provided within kit, diluted 1:1000 in wash buffer containing $1 \%$ bovine serum albumin) for $1 \mathrm{~h}$ at $37^{\circ} \mathrm{C}$. After binding of the primary antibody the wells were washed 5 times with $100 \mu \mathrm{l}$ wash buffer and incubated $1 \mathrm{~h}$ at $37^{\circ} \mathrm{C}$ with $100 \mu \mathrm{l} \mathrm{HRP}$ labeled anti-mouse-Ig antibody (as provided within kit, diluted 1:2000 in wash buffer containing $1 \%$ bovine serum albumin). Subsequently all wells were washed 5 times with $100 \mu \mathrm{l}$ wash buffer and 3 times with $100 \mu \mathrm{l}$ PBS before $100 \mu \mathrm{l}$ of the HRP substrate TMB (Cell Signaling Technology Inc., Danvers, MA, USA, Cat. No. $7004 \mathrm{~L}$ ) was added. After development of the colour during 2-5 min the reaction was aborted with $100 \mu \mathrm{l}$ stop solution (Cell Signaling Technology Inc., Danvers, MA, USA, Cat. No. 7002L) and optical density at $450 \mathrm{~nm}$ was measured with a Tecan Sunrise absorbance reader.

32. (a) Wang, S.; Wood, G.; Meades, C.; Griffiths, G.; Midgley, C.; McNae, I.; McInnes, C.; Anderson, S.; Jackson, W.; Mezna, M.; Yuill, R.; Walkinshaw, M.; Fisher, P. M. Bioorg. Med. Chem. Lett. 2004, 14, 4237. Compound 1; (b) Li, X: Prakash, R. S. J. Labelled Compd. Radiopharm. 2009, 52, 355. Compound 2; cb) Compound 3: $90 \%$ yield; $\delta_{\mathrm{H}}\left(400 \mathrm{MHz}\right.$, DMSO- $\left.d_{6}\right) 2.99(2 \mathrm{H}, \mathrm{t}, J 6.0), 3.10(2 \mathrm{H}$, $\mathrm{m}), 7.38\left(2 \mathrm{H}\right.$, br s, exchange with $\left.\mathrm{D}_{2} \mathrm{O}, \mathrm{SO}_{2} \mathrm{NH}_{2}\right), 7.44(2 \mathrm{H}, \mathrm{d}, J 8.0, \mathrm{Ar}-\mathrm{H}), 7.81$ $\left(2 \mathrm{H}, \mathrm{d}, J\right.$ 8.0, Ar-H), 8.05 (3H, br s); $\delta_{\mathrm{C}}\left(100 \mathrm{MHz}\right.$, DMSO- $\left.d_{6}\right) 35.6,40.4,126.9$, $130.1,142.5,143.6,162.4$.

33. Molecular models of compounds 4, 10, 11 were built with the MOE software suite (MOE version 2010.11, Chemical Computing Group Inc., Montreal, Quebec, Canada). Following quantum-mechanical (QM) geometry optimization at the AM1 level of theory, a single-point QM calculation at the $\mathrm{HF} / 6-31 \mathrm{G}(\mathrm{d})$ level of theory was carried out to derive atom-centered charges with the RESP method. ${ }^{38}$ The experimental crystallographic structure of human PAD4 in complex with fluoroamidine was retrieved from the Protein Data Bank (PDB ID 3B1U; resolution 2.10 ̊). The coordinates of a small number of residues were not resolved in this structure; since they were far from the enzyme cleft, the $\mathrm{C}$ - and $\mathrm{N}$-termini upstream and downstream of the missing segments were simply capped with $N$-methyl and acetyl groups, respectively. Missing hydrogen atoms were added to the three enzymes in standard positions, then optimized with the SANDER module of the AMBER software package (AMBER 10, University of California, San Francisco, CA, USA), while keeping heavy atoms harmonically restrained to the initial crystallographic coordinates with a force constant of $1000 \mathrm{kcal} \mathrm{mol}^{-1} \AA^{-2}$. After removing the co-crystallized inhibitor, compounds 4, 10, 11 were docked with AutoDock $4.2,{ }^{39}$ using a $0.375 \AA$ step size grid centered on the co-crystallized inhibitor.

34. Bertinaria, M.; Sorba, G.; Medana, C.; Cena, C.; Adami, M.; Morini, G.; Pozzoli, C.; Coruzzi, G.; Gasco, A. Helv. Chim. Acta 2000, 83, 287.

35. Bertinaria, M.; Di Stilo, A.; Tosco, P.; Sorba, G.; Poli, E.; Pozzoli, C.; Coruzzi, G.; Fruttero, R.; Gasco, A. Bioorg. Med. Chem. Lett. 2003, 11, 1197.

36. Di Stilo, A.; Cena, C.; Lolli, M.; Sorba, G.; Gasco, A.; Bertaccini, G.; Pozzoli, C.; Adami, M.; Coruzzi, G. Farmaco 1998, 53, 536.

37. CA inhibition assay. An Applied Photophysics stopped-flow instrument has been used for assaying the CA catalysed $\mathrm{CO}_{2}$ hydration activity. ${ }^{40}$ Phenol red (at a concentration of $0.2 \mathrm{mM}$ ) has been used as indicator, working at the absorbance maximum of $557 \mathrm{~nm}$, with $20 \mathrm{mM}$ Hepes (pH 7.5) as buffer, and $20 \mathrm{mM} \mathrm{Na} \mathrm{SO}_{4}$ (for maintaining constant the ionic strength), following the initial rates of the $\mathrm{CA}$-catalyzed $\mathrm{CO}_{2}$ hydration reaction for a period of 10 $100 \mathrm{~s}$. The $\mathrm{CO}_{2}$ concentrations ranged from 1.7 to $17 \mathrm{mM}$ for the determination of the kinetic parameters and inhibition constants. For each inhibitor at least six traces of the initial 5-10\% of the reaction have been used for determining the initial velocity. The uncatalyzed rates were determined in the same manner and subtracted from the total observed rates. Stock solutions of inhibitor $(0.1 \mathrm{mM})$ were prepared in distilled-deionized water and dilutions up to $0.01 \mathrm{nM}$ were done thereafter with the assay buffer. Inhibitor and enzyme solutions were preincubated together for $15 \mathrm{~min}$ at room temperature prior to assay, in order to allow for the formation of the E-I complex. The inhibition constants were obtained by non-linear least-squares methods using PRISM 3 , as reported earlier, ${ }^{41}$ and represent the mean from at least three different determinations. All CA isoforms were recombinant ones obtained in-house as reported earlier. ${ }^{42,43}$

38. Wang, J.; Cieplak, P.; Kollman, P. A. J. Comput. Chem. 2000, 21, 1049.

39. Morris, G. M.; Goodsell, D. S.; Halliday, R. S.; Huey, R.; Hart, W. E.; Belew, R. K.; Olson, A. J. J. Comput. Chem. 1998, 19, 1639.

40. Khalifah, R. G. J. Biol. Chem. 1971, 246, 2561.

41. (a) Maresca, A.; Temperini, C.; Vu, H.; Pham, N. B.; Poulsen, S. A.; Scozzafava, A.; Quinn, R. J.; Supuran, C. T. J. Am. Chem. Soc. 2009, 131, 3057; (b) Maresca, A.; Temperini, C.; Pochet, L.; Masereel, B.; Scozzafava, A.; Supuran, C. T. J. Med. Chem. 2010, 53, 335. 
42. Carta, F.; Temperini, C.; Innocenti, A.; Scozzafava, A.; Kaila, K.; Supuran, C. T. J. Med. Chem. 2010, 53, 5511.

43. (a) Di Fiore, A.; Truppo, E.; Supuran, C. T.; Alterio, V.; Dathan, N.; Bootorabi, F.; Parkkila, S.; Monti, S. M.; De Simone, G. Bioorg. Med. Chem. Lett. 2010, 20, 5023 (b) Hilvo, M.; Baranauskiene, L.; Salzano, A. M.; Scaloni, A.; Matulis, D.; Innocenti, A.; Scozzafava, A.; Monti, S. M.; Di Fiore, A.; De Simone, G.; Lindfors,
M.; Janis, J.; Valjakka, J.; Pastorekova, S.; Pastorek, J.; Kulomaa, M. S.; Nordlund, H. R.; Supuran, C. T.; Parkkila, S. J. Biol. Chem. 2008, 283, 27799.

44. Causey, P. C.; Jones, E. J.; Slack, J. L.; Kamei, D.; Jones, L. E.; Subramanian, V.; Knuckley, B.; Ebrahimi, P.; Chumanevich, A. A.; Luo, Y.; Hashimoto, H.; Sato, M.; Hofseth, L. J.; Thompson, P. R. J. Med. Chem. 2011, 54, 6919. 